\title{
Risiko Stunting Anak Baduta (7-24 bulan)
}

\author{
Dewi Sri Sumardilah ${ }^{1}$, Antun Rahmadi ${ }^{2}$ \\ ${ }^{1,2}$ Jurusan Gizi, Politeknik Kesehatan Tanjungkarang, Indonesia \\ Email: dewisrisumardilah@poltekkes-tjk.ac.id
}

\begin{abstract}
Stunting Risk for Children under Two Years (7-24 months). The results of Nutritional Status Monitoring (PSG) showed that the prevalence of stunting 29,6\% in 2017. The adverse effects of stunting in toddlers is a disorder of decreased cognitive abilities and learning achievement, decreased immunity, the risk of degenerative diseases. The city of Bandar Lampung is still faced with acute and chronic nutritional problems because the prevalence of stunting in children under five is still high. Therefore, the research conducted in Sukaraja Village, Panjang District, Bandar Lampung City, considering that the Village has the highest population of poverty compared to other villages. The aim of the research is to obtain information about the risk factors for stunting in children under two years (7-24 months) This type of research was observational using case-control design, with a sample of 53 people for the case group and 106 people for the control group where the selection for the case group and controls was done in a simple random manner. Data analysis using chi-square test. The results showed that energy consumption factors $(p=0.040)$, exclusive breastfeeding $(p=0.011)$, history of infectious diseases $(p=0.000)$, history of premature birth $(p=0.022)$, and maternal education level $(p=0.029)$ were related significantly with the incidence of stunting. While protein consumption factors $(p=0.283)$, Zink consumption $(\mathrm{p}=0.321)$, Early Breastfeeding Initiation $(\mathrm{p}=0.538)$, maternal nutrition status $(\mathrm{p}=0.056)$, maternal age $(p=0.438)$, and distance the age of birth $(p=0.188)$ was not significantly associated with the incidence of stunting of children aged 7-23 months in the Sukaraja Village of Panjang District. Regular home visits by health workers are expected to increase maternal awareness during pregnancy to have a pregnancy checked.
\end{abstract}

Keywords: Children under two years, Nutritional status, Stunting

\begin{abstract}
Abstrak: Risiko Stunting Anak Baduta (7-24 bulan). Hasil Pemantauan Status Gizi (PSG) menunjukkan bahwa secara nasional prevalensi balita pendek (stunting) pada tahun 2017 adalah $29,6 \%$. Ada banyak dampak buruk yang ditimbulkan dari masalah stunting pada balita, antara lain menurunnya kemampuan kognitif dan prestasi belajar. Masalah gizi di Bandar Lampung yang bersifat akut maupun kronis masih cukup tinggi, oleh sebab itu penelitian dilaksanakan di Kelurahan Sukaraja mengingat kelurahan tersebut memiliki jumlah penduduk dengan kemiskinan tertinggi dibandingkan dengan kelurahan lainnya. Tujuan penelitian diperolehnya informasi tentang faktor resiko kejadian stunting pada anak baduta (7-24 bulan) di Kelurahan Sukaraja Kota Bandar Lampung Tahun 2018. Jenis penelitian observasional dengan menggunakan disain case control, dengan jumlah sampel 53 orang kelompok kasus dan 106 orang kelompok kontrol dimana pemilihan untuk kelompok kasus dan kontrol dilakukan secara random sederhana. Analisis data menggunakan chi-square test. Hasil penelitian menunjukkan bahwa faktor konsumsi energi $(p=0,040)$, ASI eksklusif $(p=0,011)$, riwayat penyakit infeksi $(p=0,000)$, riwayat kelahiran prematur $(p=0,022)$, dan tingkat pendidikan ibu $(p=0,029)$ berhubungan secara bermakna dengan kejadian stunting. Sedangkan faktor konsumsi protein $(p=0,283)$, konsumsi Zink $(p=0,321)$, IMD $(p=0,538)$, Status Gizi Ibu $(p=0,056)$, umur ibu melahirkan $(p=0,438)$, dan jarak umur kelahiran $(\mathrm{p}=0,188)$ tidak berhubungan secara bermakna dengan kejadian stunting anak usia 7-24 bulan di Kelurahan Sukaraja. Kunjungan rumah secara rutin oleh tenaga kesehatan diharapkan dapat meningkatkan kesadaran ibu ketika hamil untuk memeriksakan kehamilannya.
\end{abstract}

Kata kunci: Baduta, Status gizi, Stunting

\section{PENDAHULUAN}

Penurunan prevalensi balita pendek (stunting) merupakan salah satu program prioritas dalam pembangunan kesehatan periode tahun
2015-2019 disamping penurunan angka kematian ibu dan bayi, pengendalian penyakit menular, dan pengendalian penyakit tidak menular. Dengan demikian, penurunan prevalensi balita pendek telah tercantum di dalam sasaran pokok Rencana 
Pembangunan Jangka Menengah Tahun 20152019. Balita pendek adalah balita dengan status gizi yang berdasarkan panjang atau tinggi badan menurut umurnya bila dibandingkan dengan standar baku WHO-MGRS (Multicentre Growth Reference Study) tahun 2005, nilai z-scorenya kurang dari -2 SD dan dikategorikan sangat pendek jika nilai $z$-score-nya kurang dari $-3 \mathrm{SD}$ (Kemenkes, 2016).

Ada banyak hal yang mendasari mengapa penurunan prevalensi balita pendek menjadi prioritas dalam pembangunan kesehatan. Hal ini terkait dengan jumlahnya yang masih sangat tinggi dan dampak yang ditimbulkannya juga sangat besar. Hasil Pemantauan Status Gizi (PSG) menunjukkan bahwa prevalensi balita pendek kecenderungannya terus meningkat, yaitu dari $22,6 \%$ pada tahun 2015 , menjadi $27,5 \%$ pada tahun 2016, dan menjadi 29,6\% pada tahun 2017. Khusus untuk Propinsi Lampung, prevalensi balita pendek juga menunjukkan kecenderungan yang terus meningkat. Berdasarkan data PSG tahun 2015 diketahui bahwa prevalensi balita pendek mencapai $22,6 \%$, kemudian meningkat menjadi $24,8 \%$ pada tahun 2016, dan menjadi 31,6\% pada tahun 2017 (Kemenkes 2016; 2018). Jika mengacu pada batasan yang dikeluarkan oleh WHO maka masalah balita pendek baik di tingkat nasional maupun di Provinsi Lampung masih menjadi masalah kesehatan masyarakat karena prevalensinya masih di atas $20 \%$.

Ada beberapa dampak buruk yang ditimbulkan dari masalah stunting pada balita, baik pada masa sekarang maupun masa yang akan datang. Dalam jangka pendek, stunting dapat mengakibatkan terganggunya perkembangan otak, kecerdasan, gangguan pertumbuhan fisik, dan gangguan metabolisme dalam tubuh. Sedangkan dalam jangka panjang akibat buruk yang dapat ditimbulkan adalah menurunnya kemampuan kognitif dan prestasi belajar, menurunnya kekebalan tubuh sehingga mudah sakit, dan risiko tinggi untuk munculnya penyakit diabetes, kegemukan, penyakit jantung dan pembuluh darah, kanker, stroke, dan disabilitas pada usia tua, serta kualitas kerja yang tidak kompetitif yang berakibat pada rendahnya produktivitas ekonomi.

Balita pendek (stunting) diketahui mempunyai nilai rata-rata IQ 11 poin lebih rendah jika dibandingkan dengan anak yang normal (UNICEF 2005). Stunting juga dapat meningkatkan resiko obesitas. Bila keadaan obesitas dibiarkan berlangsung lama maka resiko menderita penyakit degeneratif juga dapat meningkat (Anugraheni, 2012). Hasil studi longitudinal pada anak-anak di Brazil, Guatemala, India, Filipina, dan Afrika Selatan tentang reduction in schooling membuktikan bahwa anak yang mengalami stunting pada usia dua tahun akan mengalami keterlambatan dalam menyelesaikan sekolahnya selama hampir satu tahun (Martorell dkk. 2010; Adair dkk. 2013). Kemudian hasil penelitian meta analisis dari 45 studi longitudinal di Amerika Serikat menunjukkan bahwa terdapat hubungan yang signifikan antara tinggi badan dengan sukses karir dan gaji di lingkungan pekerjaan. Seseorang dengan tinggi badan $182 \mathrm{~cm}$, rata-rata menghasilkan gaji selama 30 tahun berkarir sekitar \$166.000 lebih tinggi jika dibandingkan dengan seseorang dengan tinggi badan $155 \mathrm{~cm}$ (Judge dkk, 2004). Hal ini menunjukkan bahwa tinggi badan seseorang mempengaruhi pendapatan dan produktivitas kerjanya.

Dari berbagai hasil penelitian tentang stunting dapat diketahui bahwa selain infeksi, stunting juga berhubungan dengan defisiensi gizi (mikronutrien dan makronutrien). Terdapat beberapa zat gizi yang berkaitan dengan stunting seperti protein, zat besi, zink, kalsium, dan vitamin D, A dan C. Selain itu, faktor hormon, genetik dan rendahnya pengetahuan orangtua dalam pengasuhan, kemiskinan, rendahnya sanitasi lingkungan, rendahnya aksesibilitas pangan pada tingkat keluarga terutama pada keluarga miskin, dan rendahnya akses keluarga terhadap pelayanan kesehatan dasar menjadi faktor resiko anak menderita stunting.

Faktor lain yang diketahui mempengaruhi kejadian stunting adalah berat badan lahir, panjang badan lahir, usia kehamilan dan pola asuh ibu. Defisiensi energi kronis atau anemia selama kehamilan dapat menyebabkan ibu melahirkan bayi dengan berat lahir rendah. Tingginya angka BBLR diperkirakan menjadi penyebab tingginya kejadian stunting di Indonesia. Hasil penelitian Espo, dkk (2002) di Malawi menunjukkan bahwa berat badan lahir rendah merupakan prediktor terkuat kejadian stunting pada balita usia 12 bulan. Pertumbuhan linier bayi berat lahir rendah dengan usia kehamilan $\geq 37$ minggu (disebut bayi IUGR) lebih lambat dari pada bayi normal. Namun, pertumbuhan bayi BBLR prematur (usia kehamilan <37 minggu) dalam lingkungan yang mendukung akan tumbuh lebih baik daripada bayi IUGR, jika berat lahir bayi sesuai dengan usia kehamilan. Penelitian Rahayu di Tangerang (2011) dengan desian kohort menunjukkan bayi yang lahir prematur memiliki risiko 2 kali lebih besar dibanding bayi yang lahir normal untuk menjadi stunting pada usia 6-12 bulan. Faktor lain yang berhubungan dengan stunting adalah asupan ASI Eksklusif pada balita. Penelitian di Ethiopia Selatan membuktikan bahwa balita yang 
tidak mendapatkan ASI eksklusif selama 6 bulan berisiko tinggi mengalami stunting (Fikadu dkk, 2014).

Penelitian cross sectional yang dilakukan oleh Aridiyah dkk (2015) pada 100 orang anak balita di wilayah pedesaan dan perkotaan di Kabupaten Jembar menunjukkan bahwa faktor pendidikan ibu, pendapatan keluarga, pengetahuan ibu mengenai ASI, pemberian ASI eksklusif, umur pemberian MP-ASI, tingkat kecukupan Zink, dan riwayat penyakit infeksi ternyata mempengaruhi terjadinya stunting. Kemudian penelitian case control yang dilakukan oleh Ni'mah dan Nadhiroh (2016) pada 64 orang anak usia 12-59 bulan di wilayah kerja Puskesmas Tanah Kali Kedinding Kota Surabaya menunjukkan bahwa ada hubungan antara riwayat ASI eksklusif, pendapatn keluarga, pendidikan ibu dengan kejadian stunting pada balita.

Hasil PSG tahun 2017 memberikan gambaran bahwa masalah stunting (balita pendek) masih menjadi masalah kesehatan masyarakat di Provinsi Lampung karena prevalensinya masih di atas 20\% (rentangnya antara 23,5\% sampai 37,3\%). Ada 5 (lima) kabupaten/kota yang memiliki prevalensi tertinggi untuk balita pendek yaitu kabupaten Lampung Barat (37,3\%), Tanggamus $(37,3 \%)$, Lampung Tengah (37,0\%), Lampung Utara $(34,9 \%)$, dan Bandar Lampung $(33,4 \%)$. Jika dibandingkan dengan hasil PSG tahun 2016 maka kenaikan terbesar prevalensi balita pendek secara berurutan ditempati oleh Kabupaten Lampung Utara (51,1\%), Kabupaten Tanggamus $(50,4 \%)$, Kota Bandar Lampung (49,8\%), dan Kabupaten Lampung Tengah $(41,2 \%)$.

Meskipun Kota Bandar Lampung termasuk sebagai daerah perkotaan tetapi jika dibandingkan dengan kabupaten lainnya ternyata keadaan gizi balitanya tidak lebih baik, Tercatat bahwa selain prevalensi balita pendek yang masih tinggi, ternyata prevalensi balita gizi kurang dan prevalensi balita kurus di Kota Bandar Lampung adalah yang paling tinggi jika dibandingkan dengan kabupaten lainnya. Hal ini menjadi sangat menarik untuk diteliti karena sebagai daerah perkotaan ternyata Kota Bandar Lampung masih dihadapkan pada masalah gizi yang bersifat akut dan kronis. Penelitian dilaksanakan di Kelurahan Sukaraja Kecamatan Panjang Kota Bandar Lampung mengingat kelurahan tersebut memiliki jumlah penduduk dengan kemiskinan tertinggi dibandingkan dengan kelurahan lainnya (Dinkes Kota Bandar Lampung, 2017).
Berdasarkan uraian di atas maka menjadi menarik untuk meneliti apa faktor resiko kejadian stunting pada anak usia 7-24 bulan di Kelurahan Sukaraja Kecamatan Panjang Kota Bandar Lampung Tahun 2018? Dengan demikian, tujuan yang ingin dicapai dalam penelitian ini adalah diperolehnya informasi tentang faktor resiko stunting pada anak usia 7-24 bulan di Kelurahan Sukaraja Kecamatan Panjang Kota Bandar Lampung Tahun 2018.

Lingkup yang dicakup dalam penelitian ini adalah stunting sebagai variabel dependen, kemudian konsumsi zat gizi (energi, protein, dan zink), ASI eksklusif, Inisiasi menyusui dini, Riwayat penyakit infeksi, Status gizi ibu, Usia ibu melahirkan, Riwayat kelahiran prematur, Jarak kelahiran, dan tingkat pendidikan ibu sebagai variabel independen. Penelitian dilakukan pada anak usia 7-24 bulan di Kelurahan Sukaraja Kecamatan Panjang Kota Bandar Lampung pada bulan Juli sampai dengan November 2018.

\section{METODE}

Penelitian ini bersifat observasi dengan menggunakan pendekatan case control. Populasi penelitian seluruh anak yang berumur antara $7 \mathrm{~s} / \mathrm{d}$ 24 bulan yang berada di Kelurahan Sukaraja Kecamatan Panjang Kota Bandar Lampung, sampai dengan bulan April 2018 tercatat anak yang berumur $7 \mathrm{~s} / \mathrm{d} 24$ bulan berjumlah 298 orang. Di pilihnya anak usia 7-24 bulan sebagai subjek penelitian ini dengan pertimbangan, pertama: prevalensi stunting pada usia tersebut cukup tinggi. Kedua: bahwa kemampuan ibu untuk mengingat kejadian sampai anaknya usia 24 bulan diperkirakan masih cukup baik.

Pada penelitian ini diambil sejumlah sampel. Sampel yang akan digunakan terkelompok menjadi dua, yaitu kelompok kasus dan kelompok kontrol dengan perbandingan $1: 2$. Kasus adalah anak usia 7-24 bulan yang tinggi badannya termasuk dalam kategori pendek ( $\mathrm{Z}$ score >-2 SD), sedangkan kontrol adalah anak usia 7-24 bulan yang tinggi badannya tidak termasuk dalam kategori pendek.

Rumus yang digunakan untuk menghitung jumlah sampel minimal untuk tiap kelompok adalah sebagai berikut:

$$
\begin{gathered}
\mathrm{n}=\frac{\left\{\mathrm{Z}_{1-\alpha / 2} \downarrow\left(2 \mathrm{P}_{2} \times\left(1-\mathrm{P}_{2}\right)\right\}+\mathrm{Z}_{1-\beta} \downarrow\left\{\mathrm{P}_{1} \times\left(1-\mathrm{P}_{1}\right) \times \mathrm{P}_{2} \times\left(1-\mathrm{P}_{2}\right)\right\}^{2}\right.}{\mathrm{OR} \times \mathrm{P}_{2}}\left(\mathrm{P}_{1}-\mathrm{P}_{2}\right)^{2} \\
\mathrm{P}_{1}=\frac{\left.-\mathrm{OR} \times \mathrm{P}_{2}\right)+\left(1-\mathrm{P}_{1}\right)}{(\mathrm{O})}
\end{gathered}
$$


dengan tingkat kemaknaan 5\% dan kekuatan uji sebesar $80 \%$ serta tingkat keterpaparan prematuritas pada anak yang tidak stunting yaitu sebesar 45\% dengan OR sebesar 3,5 (Meilyasari dan Muflihah Isnawati (2014), maka diperoleh jumlah sampel untuk kelompok kasus adalah 53 orang dan sebagai kelompok kontrol 106 orang. Pengambilan sampel untuk kelompok kasus maupun kelompok kontrol dilakukan secara random, hal ini dimaksudkan untuk mengontrol variabel pengganggu. Sedangkan kriteria inklusi dan eksklusi yang digunakan dalam pemilihan sampel adalah sebagai berikut:
a. Kriteria Inklusi
1) Pada saat pengukuran dilakukan anak berumur 7 s/d 24 bulan
2) Bersedia menjadi responden

b. Kriteria Eksklusi
1) Memiliki kondisi fisik yang dapat mengganggu hasil pengukuran tinggi/panjang badannya
2) Tidak berada ditempat ketika pengukuran akan dilakukan

Penelitian dilakukan di Kelurahan Sukaraja Kecamatan Panjang Kota Bandar Lampung pada bulan Juli sampai dengan November 2018. Instrumen yang digunakan dalam penelitian ini adalah Mikrotoise/Infantometer untuk mengukur tinggi badan ibu dan anak, kuesioner untuk mengukur praktek pemberian ASI, IMD, riwayat infeksi, riwayat kelahiran, jarak kelahiran, umur, dan pendidikan ibu, sedangkan Formulir Food Recall untuk mengukur tingkat konsumsi energi, protein, dan zink. Pengumpulan data dilakukan dengan cara mengukur dan wawancara oleh peneliti dibantu oleh 8 orang enumerator yang sudah dilatih, yaitu mahasiswa jurusan gizi Poltekes Kemenkes Tanjungkarang tingkat akhir yang sebelumnya telah dilakukan penyamaan persepsi melalui pelatihan singkat. Analisis data dilakukan dengan cara melihat distribusi frekuensi masing-masing variabel dan melihat hubungan antara variabel independen dengan variabel dependen dengan menggunakan uji chisquare.

\section{HASIL}

Tabel 1. Karakteristik Kasus dan Kontrol

\begin{tabular}{lcccc}
\hline \multirow{2}{*}{ Kelompok } & \multicolumn{2}{c}{ Umur (Bulan) } & \multicolumn{2}{c}{ Jenis Kelamin } \\
\cline { 2 - 5 } & $\mathbf{7 - 1 1}$ & $\mathbf{1 2 - 2 4}$ & $\begin{array}{c}\text { Laki- } \\
\text { laki }\end{array}$ & Perempuan \\
\hline Kasus & 7 & 46 & 29 & 24 \\
\hline Kontrol & 50 & 56 & 57 & 49 \\
\hline
\end{tabular}

Pada tabel 1 dapat dilihat bahwa 46 orang $(86,8 \%)$ responden pada kelompok kasus memiliki umur antara 12-24 bulan, kemudian jumlah laki-laki dan perempuan relatif seimbang. Sedangkan pada kelompok kontrol, umur responden tersebar hampir merata demikian pula dengan sebaran jenis kelamin.

Pada kelompok kasus, rata-rata tinggi badan adalah $71,8 \pm 1,66 \mathrm{~cm}$ dan rata-rata umur adalah $16,2 \pm 1,28$ bulan, sedangkan pada kelompok kontrol rata-rata tinggi badan adalah $74,4 \pm 1,46 \mathrm{~cm}$ dan rata-rata umur 13,1 $\pm 0,29$ bulan. Dengan demikian, tampak bahwa responden pada kelompok kontrol memiliki rata-rata umur yang lebih muda dibandingkan dengan responden pada kelompok kasus tetapi memiliki rata-rata tinggi badan yang lebih baik.

Tabel 2. Distribusi Frekuensi Faktor Resiko Stunting

\begin{tabular}{|c|c|c|}
\hline \multirow{2}{*}{ Faktor Resiko } & \multicolumn{2}{|c|}{ Jumlah } \\
\hline & $\mathbf{n}$ & $\%$ \\
\hline \multicolumn{3}{|l|}{ Konsumsi Energi (kkal) : } \\
\hline$<80 \% \mathrm{AKG}$ & 113 & 71,1 \\
\hline$\geq 80 \% \mathrm{AKG}$ & 46 & 28,9 \\
\hline \multicolumn{3}{|l|}{ Konsumsi Protein (gr) : } \\
\hline$<80 \% \mathrm{AKG}$ & 87 & 54,7 \\
\hline$\geq 80 \% \mathrm{AKG}$ & 72 & 45,3 \\
\hline \multicolumn{3}{|l|}{ Konsumsi Zink (mg) : } \\
\hline$<80 \% \mathrm{AKG}$ & 119 & 74,8 \\
\hline$\geq 80 \% \mathrm{AKG}$ & 40 & 25,2 \\
\hline \multicolumn{3}{|l|}{ Pemberian ASI : } \\
\hline Tidak Eksklusif & 107 & 67,3 \\
\hline Eksklusif & 52 & 32,7 \\
\hline \multicolumn{3}{|l|}{ IMD : } \\
\hline Tidak & 79 & 49,7 \\
\hline $\mathrm{Ya}$ & 80 & 50,3 \\
\hline \multicolumn{3}{|l|}{ Riwayat Infeksi : } \\
\hline Pernah & 79 & 49,7 \\
\hline Tidak Pernah & 80 & 50,3 \\
\hline \multicolumn{3}{|l|}{ St. Gizi Ibu : } \\
\hline Pendek & 130 & 81,8 \\
\hline Normal & 29 & 18,2 \\
\hline \multicolumn{3}{|l|}{ Riwayat Kelahiran : } \\
\hline Prematur & 24 & 15,1 \\
\hline Tidak Prematur & 135 & 84,9 \\
\hline \multicolumn{3}{|c|}{ Umur Ibu Saat Melahirkan } \\
\hline Beresiko & 23 & 14,5 \\
\hline Tidak Beresiko & 136 & 85,5 \\
\hline \multicolumn{3}{|l|}{ Jarak kelahiran dg Kakak } \\
\hline$<1$ tahun & 9 & 7,7 \\
\hline$\geq 1$ tahun & 108 & 92,3 \\
\hline \multicolumn{3}{|l|}{ Tingkat Pendidikan Ibu : } \\
\hline Rendah & 67 & 42,1 \\
\hline Tinggi & 92 & 57,9 \\
\hline
\end{tabular}

Dari seluruh responden yang berhasil diukur ternyata rata-rata konsumsi energi hanya sebesar 419,4 kkal perhari. Rata-rata konsumsi energi pada kelompok kasus lebih tinggi jika dibandingkan dengan kelompok kontrol. Pada kelompok kasus rata-rata konsumsi energi mencapai 563,9 $\pm 169,2$ kkal perhari, sedangkan pada kelompok kontrol hanya 347,1 $\pm 99,6$ kkal perhari. Ketika jumlah konsumsi energi 
responden dibandingkan dengan AKG maka diketahui ada 113 orang $(71,1 \%)$ yang tingkat konsumsinya kurang dari $80 \%$ AKG.

Untuk konsumsi protein, rata-rata konsumsi protein responden adalah 12,3 gram. Pada kelompok kasus, rata-rata konsumsi protein hanya $11,8 \pm 5,3$ gram per hari, sedangkan pada kelompok kontrol 12.6 $\pm 6,0$ gram perhari. Jika konsumsi protein responden dibandingkan dengan $\mathrm{AKG}$ maka ada 87 orang $(54,7 \%)$ responden yang tingkat konsumsinya kurang dari $80 \%$ AKG.

Rata-rata Zink yang dikonsumsi oleh responden adalah $1,5 \mathrm{mg}$ perhari. Kelompok kasus rata-rata hanya mengkonsumsi Zink 1,4 $\pm 0,4 \mathrm{mg}$ perhari, sedangkan kelompok kontrol rata-rata

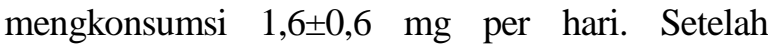
dibandingkan dengan AKG maka sebagian besar responden $(74,8 \%)$ mengkonsumsi zink kurang dari $80 \%$ Angka Kecukupan Gizi yang dianjurkan (AKG).

Dalam hal pemberian ASI, diketahui bahwa hanya 52 orang $(32,7 \%)$ responden yang mendapatkan ASI secara eksklusif. Sebagian besar di antara mereka $(57,2 \%)$ mendapatkan ASI secara eksklusif hanya sampai umur kurang atau sama dengan 3 bulan. Ada banyak alasan yang disampaikan oleh ibu responden sehingga responden tidak mendapatkan ASI secara eksklusif, antara lain karena ASI tidak keluar $(59,2 \%)$, jumlah ASI sedikit (14,8\%), ibu sakit $(5,9 \%)$, dan lain-lain $(37,1 \%)$. Proporsi responden yang mendapatkan IMD maupun tidak mendapatkan IMD besarnya relatif seimbang. Padahal kelahiran responden 99,4\% ditolong oleh tenaga kesehatan (bidan atau dokter).

Pada tabel di atas juga tampak bahwa responden yang memiliki riwayat penyakit infeksi dan yang tidak memiliki riwayat penyakit infeksi pada satu bulan sebelum pengukuran ternyata jumlahnya relatif sama. Adapun jenis penyakit infeksi yang paling banyak diderita responden adalah batuk pilek $(82,1 \%)$ dan diare $(15,0 \%)$.

Hasil pengukuran status gizi ibu responden dengan menggunakan indeks Tinggi Badan menurut Umur (TB/U) dapat diketahui bahwa $81,8 \%$ ibu responden tergolong pendek, selebihnya masuk dalam kategori normal sampai tinggi. Kemudian sebagian besar ibu $(86,1 \%)$ ketika melahirkan responden berumur antara 2135 tahun, dengan demikian hanya 13,9\% yang melahirkan berada pada umur resiko tinggi. Responden yang memiliki riwayat kelahiran prematur berjumlah 24 orang $(15,1 \%)$.

Untuk faktor jarak umur kelahiran, data hanya bisa diperoleh dari 117 orang responden karena 42 orang diantaranya diketahui tidak mempunyai kakak, dan hasilnya adalah hanya $7,7 \%$ responden yang memiliki jarak umur kelahirannya kurang dari 1 tahun dari kakaknya. Selanjutnya sebesar $42,1 \%$ ibu responden memiliki tingkat pendidikan rendah, yaitu mulai dari tamat SD sampai dengan tamat SMP. Sedangkan $57,9 \%$ lainnya memiliki tingkat pendidikan tinggi (tamat SMA dan tamat PT).

\section{Tabel 3. Hubungan Faktor Resiko dengan Stunting pada Kelompok Kasus dan Kontrol}

\begin{tabular}{|c|c|c|c|c|c|c|}
\hline & \multicolumn{4}{|c|}{ Kelompok } & \multirow{3}{*}{$p$} & \multirow{3}{*}{$\begin{array}{c}\text { OR } \\
95 \% \mathrm{CI}\end{array}$} \\
\hline & \multicolumn{2}{|c|}{ Kasus } & \multicolumn{2}{|c|}{ Kontrol } & & \\
\hline & $\mathrm{n}$ & $\%$ & $\mathbf{n}$ & $\%$ & & \\
\hline \multicolumn{7}{|l|}{ Kons. Energi } \\
\hline$<80 \% \mathrm{AKG}$ & 43 & 81,1 & 70 & 66,0 & \multirow{2}{*}{0,04} & 2,27 \\
\hline$\geq 80 \% \mathrm{AKG}$ & 10 & 18,9 & 36 & 34,0 & & $1,02-5,03$ \\
\hline \multicolumn{7}{|l|}{ Kons. Protein } \\
\hline$<80 \% \mathrm{AKG}$ & 32 & 60,4 & 55 & 51,9 & \multirow{2}{*}{0,28} & \\
\hline$\geq 80 \% \mathrm{AKG}$ & 21 & 39,6 & 51 & 48,1 & & \\
\hline \multicolumn{7}{|l|}{ Kons. Zink } \\
\hline$<80 \% \mathrm{AKG}$ & 42 & 79,2 & 77 & 72,6 & \multirow{2}{*}{0,32} & \\
\hline$\geq 80 \% \mathrm{AKG}$ & 11 & 20,8 & 29 & 27,4 & & \\
\hline \multicolumn{7}{|l|}{ Pemberian ASI } \\
\hline Tidak Eksklusif & 33 & 62,3 & 74 & 69,8 & \multirow{2}{*}{0,01} & 4,03 \\
\hline Eksklusif & 20 & 37,7 & 32 & 30,2 & & $1,37-11,8$ \\
\hline \multicolumn{7}{|l|}{ IMD } \\
\hline Tidak & 28 & 52,8 & 51 & 48,1 & \multirow{2}{*}{0,53} & \\
\hline $\mathrm{Ya}$ & 25 & 47,2 & 55 & 51,9 & & \\
\hline \multicolumn{7}{|l|}{ Riw. Infeksi } \\
\hline Pernah & 43 & 81,1 & 36 & 33,9 & \multirow{2}{*}{0,00} & 8,80 \\
\hline Tidak Pernah & 10 & 18,9 & 70 & 66,1 & & $3,32-22,4$ \\
\hline \multicolumn{7}{|l|}{ St. Gizi Ibu : } \\
\hline Pendek & 49 & 92,4 & 81 & 76,4 & \multirow{2}{*}{0,05} & \\
\hline Normal & 4 & 7,6 & 25 & 23,6 & & \\
\hline \multicolumn{7}{|l|}{ Riwayat lahir : } \\
\hline Prematur & 18 & 33,9 & 6 & 5,7 & \multirow{2}{*}{0,02} & 7,3 \\
\hline Tidak Prematur & 35 & 66,1 & 100 & 94,3 & & $1,31-45,6$ \\
\hline \multicolumn{7}{|l|}{$\begin{array}{l}\text { Umur Ibu Saat } \\
\text { Melahirkan }\end{array}$} \\
\hline Beresiko & 6 & 11,3 & 17 & 16,0 & \multirow{2}{*}{0,43} & \\
\hline Tidak Beresiko & 47 & 88,7 & 89 & 84,0 & & \\
\hline
\end{tabular}

\begin{tabular}{lrrrrrr}
$\begin{array}{l}\text { Jarak } \\
\text { kelahiran } \\
\text { dengan Kakak }\end{array}$ & & & & & & \\
$<1$ tahun & 1 & 2,7 & 8 & 10,0 & 0,18 & \\
$\geq 1$ tahun & 36 & 97,3 & 72 & 90,0 & & \\
\hline Tingkat & & & & & & 3,34 \\
$\begin{array}{l}\text { Pendidikan Ibu } \\
\text { Rendah }\end{array}$ & 33 & 62,3 & 34 & 32,1 & & \\
Tinggi & 20 & 37,7 & 72 & 67,9 & 0,02 & $1,24-9,15$ \\
\hline
\end{tabular}

Dari tabel 3 dapat diketahui bahwa baik pada kelompok kasus maupun kelompok kontrol pada umumnya memiliki tingkat konsumsi energi yang rendah. Tercatat bahwa 43 orang $(81,1 \%)$ pada kelompok kasus mengkonsumsi energi perhari kurang dari $80 \%$ AKG. Sedangkan pada kelompok kontrol jumlahnya mencapai $66,0 \%$. Hasil uji chi-square menunjukkan bahwa secara statistik ada hubungan yang bermakna antara tingkat konsumsi energi responden dengan kejadian stunting $(p=0,04 ; \quad \mathrm{OR}=2,27 ; \quad \mathrm{CI}$ 
$95 \%=1,026-5,034)$. Dengan demikian, responden dengan tingkat konsumsi energi kurang dari $80 \%$ AKG memiliki resiko sebesar 2,27 kali untuk mengalami stunting dibandingkan dengan responden yang memiliki tingkat konsumsi energi lebih atau sama dengan $80 \%$ AKG.

Tingkat konsumsi protein pada kedua kelompok sebagian besar ternyata masuk dalam kategori kurang dari $80 \%$ AKG. Pada kelompok kasus ada 32 orang $(60,4 \%)$ yang tingkat konsumsi proteinnya rendah, sedangkan pada kelompok control ada 55 orang $(51,9 \%)$. Hasil uji chi-square menunjukkan bahwa secara statistik tidak ada hubungan yang bermakna antara tingkat konsumsi protein dengan kejadian stunting $(p>0,05)$.

Demikian pula halnya dengan konsumsi zink, konsumsi zink pada kedua kelompok tergolong rendah (kurang dari $80 \%$ AKG) dan proporsinya relative sama. Hasil uji chi-square menunjukkan bahwa secara statistik tidak ada hubungan yang bermakna antara tingkat konsumsi zink dengan kejadian stunting $(p>0,05)$.

Pada kelompok kasus, yang tidak mendapatkan ASI secara eksklusif mencapai $62,3 \%$, sedangkan pada kelompok kontrol mencapai $69,8 \%$. Secara statistik ditemukan ada hubungan yang bermakna antara pemberian ASI eksklusif dengan kejadian stunting ( $p=0,011$; $\mathrm{OR}=4,03 ; \quad$ CI $\quad 95 \%=1,37-11,8)$. Artinya, responden yang tidak mendapatkan ASI secara eksklusif memiliki resiko sebesar 4,03 kali untuk menjadi stunting jika dibandingkan dengan responden yang mendapatkan ASI secara eksklusif.

Responden pada kelompok kasus yang tidak mendapatkan Inisiasi Menyusui Dini (IMD) jumlahnya mencapai 28 orang $(52,8 \%)$, sedangkan responden pada kelompok kontrol berjumlah 51 orang $(48,1 \%)$. Hasil uji statistik menunjukkan bahwa tidak ada hubungan yang bermakna antara IMD dengan kejadian stunting $(p>0,05)$.

Sebagian besar responden pada kelompok kasus $(81,1 \%)$ diketahui pernah menderita penyakit infeksi, sedangkan pada kelompok kontrol $66,1 \%$ tidak pernah menderita penyakit infeksi. Setelah dilakukan analisa chi-square maka diketahui bahwa secara statistik ada hubungan yang bermakna antara riwayat penyakit infeksi dengan kejadian stunting $(p=0,00$; $\mathrm{OR}=8,80 ; \quad$ CI $95 \%=3,32-22,39)$. Sehingga, responden yang memiliki riwayat pernah menderita penyakit infeksi memiliki resiko sebesar 8,8 kali untuk menjadi stunting jika dibandingkan dengan responden yang tidak memiliki riwayat menderita penyakit infeksi.

Sebagian besar ibu responden, baik yang berada pada kelompok kasus maupun kelompok kontrol, ternyata memiliki status gizi dengan kategori pendek. Pada kelompok kasus jumlahnya mencapai $92,4 \%$ sedangkan pada kelompok kontrol mencapai 76,4\%. Hasil analisa hubungan dengan menggunakan uji chi-square dapat diketahui bahwa secara statistik tidak ada hubungan yang bermakna antara status gizi ibu dengan kejadian stunting $(p>0,05)$.

Dilihat dari faktor umur ibu ketika melahirkan responden, maka sebagian besar ibu melahirkan pada umur yang tidak beresiko.Pada kelompok kasus besarannya mencapai 88,7\% sedangkan pada kelompok kontrol $84,0 \%$. Hasil uji chi-square menunjukkan tidak ada hubungan yang bermakna antara status gizi ibu dengan kejadian stunting $(p>0,05)$.

Selanjutnya, diketahui bahwa $66,1 \%$ responden pada kelompok kasus mempunyai riwayat kelahiran tidak prematur, sedangkan pada kelompok kontrol mencapai 94,3\%. Secara statistik ada hubungan yang bermakna antara riwayat kelahiran prematur dengan kejadian stunting ( $p=0,022$; $\mathrm{OR}=7,3$; CI 95\%=1,31-45,6). Dengan demikian, responden dengan riwayat kelahiran prematur memiliki resiko 7,3 kali untuk menjadi stunting dibandingkan dengan responden yang memiliki riwayat kelahiran tidak prematur.

Sebagian besar responden memiliki jarak umur kelahiran dengan kakaknya lebih dari 2 tahun, yaitu 97,3\% pada kelompok kasus dan 90,0\% pada kelompok kontrol. Dari analisa bivariate diketahui bahwa secara statistik tidak ada hubungan yang bermakna antara status gizi ibu dengan kejadian stunting ( $p>0,05)$.

Untuk kepentingan analisa, variabel tingkat pendidikan ibu responden hanya dikategorikan menjadi 2 (dua), yaitu rendah (sampai dengan lulus SMP) dan tinggi (lulus SMA dan PT). Pada kelompok kasus, 62,3\% tingkat pendidikan ibu tergolong rendah, sedangkan pada kelompok kontrol hanya $32,1 \%$. Dari hasil uji chi-square dapat diketahui bahwa secara statistik ada hubungan yang bermakna antara tingkat pendidikan ibu responden dengan kejadian stunting $(p=0,029 ; \quad \mathrm{OR}=3,34 ; \quad \mathrm{CI}$ $95 \%=1,24-9,15)$. Artinya, responden dengan ibu berpendidikan rendah memiliki resiko sebesar 3,34 kali untuk menjadi stunting dibandingkan dengan responden dengan ibu berpendidikan tinggi. 


\section{PEMBAHASAN}

\section{Hubungan Tingkat Konsumsi Energi dengan Stunting}

Hasil penelitian ini menunjukkan bahwa secara statistik ada hubungan yang bermakna antara tingkat konsumsi energi dengan kejadian stunting pada anak usia 7-24 bulan di Kelurahan Sukaraja. Hasil yang sejalan ditunjukkan oleh Oktarina (2014) yang menganalisis data Riskesdas 2010 dari 4 propinsi (Aceh, Sumatera Utara, Sumatera Selatan, dan Lampung), bahwa ada hubungan antara tingkat konsumsi energi dengan kejadian stunting, meskipun sampel yang dianalisis adalah balita usia 24-59 bulan. Disebutkan oleh Oktarina bahwa balita yang mempunyai tingkat konsumsi energi rendah mempunyai resiko 1,28 kali untuk mengalami stunting dibandingkan dengan balita yang memiliki tingkat konsumsi energi cukup. Hal ini juga sesuai dengan teori UNICEF yang menyatakan bahwa konsumsi makanan yang tidak adekuat merupakan salah satu faktor penyebab langsung dapat menyebabkan stunting (UNICEF, 2005). Sebuah studi yang dilakukan oleh Xiaoli dkk (2009) juga menunjukkan bahwa penyebab kejadian stunting di Cina adalah defisiensi energi dan protein yang telah berlangsung dalam jangka panjang.

WHO (2013) menyebutkan bahwa stunting dapat disebabkan karena makanan yang tidak adekuat, antara lain karena kualitas makanan yang rendah dan cara pemberian yang tidak adekuat. Kualitas makanan yang rendah dapat berupa kualitas mikronutrien yang rendah, keragaman jenis makanan yang dikonsumsi dan sumber makanan hewani yang rendah, makanan yang tidak mengandung nutrisi, dan makanan komplementer yang mengandung energi rendah. Sedangkan cara pemberian yang tidak adekuat dapat berupa frekuensi pemberian makanan yang rendah, pemberian makanan yang tidak adekuat ketika sakit dan setelah sakit, konsistensi makanan yang terlalu halus, dan pemberian makan yang rendah dalam kuantitas. Kualitas makanan yang tidak adekuat dan berlangsung lama/kronis dapat menyebabkan anak menderita stunting.

Untuk membantu meningkatkan konsumsi energi, khususnya pada anak usia di atas 6 bulan, selain anak mendapatkan makanan yang berasal dari rumah maka perlu ditingkatkan program pemberian makanan pendamping ASI pabrikan.

\section{Hubungan Tingkat Konsumsi Protein dengan Stunting}

Dari hasil uji chi-square dapat diketahui bahwa dalam penelitian ini tidak ditemukan adanya hubungan antara konsumsi protein dengan kejadian stunting. Hal ini sama seperti yang dihasilkan dari hasil penelitian Priyono dkk (2015) yang menyatakan bahwa tidak ada hubungan yang bermakna antara tingkat konsumsi protein dengan kejadian stunting pada anak balita usia 12-36 bulan di wilayah kerja Puskesmas Randuagung Kabupaten Lumajang. Namun demikian, hasil yang berbeda ditunjukkan dari penelitian Fitri (2012) yang mendasarkan pada analisis data RISKESDAS 2010 yang menyatakan bahwa terdapat hubungan yang bermakna antara konsumsi protein dengan kejadian stunting pada anak balita usia 12-59 bulan di Pulau Sumatera.

Alasan tidak ditemukannya hubungan antara tingkat konsumsi protein dengan kejadian stunting pada balita diduga disebabkan karena beberapa faktor. Pertama, Kejadian stunting merupakan peristiwa yang terjadi dalam periode waktu lama, sehingga tingkat konsumsi protein yang terjadi sekarang tidak menjadi salah satu penyebab kejadian stunting. Kemudian konsumsi protein juga bukan satu satunya faktor yang mempengaruhi kejadian stunting. Faktor lain yang menjadikan anak menderita stunting adalah defisiensi zat gizi mikro, zat gizi dalam kandungan, ukuran tubuh ibu, dan infeksi (Lee dkk, 2010). Kekurangan zat gizi mikro berperan dalam proses pertumbuhan, seperti zink dan vitamin A. Vitamin A berperan dalam proses sintesis protein, sehingga berpengaruh terhadap pertumbuhan sel. Pada anak-anak yang kekurangan vitamin A, terjadi kegagalan pertumbuhan.

\section{Hubungan Tingkat Konsumsi Zink dengan Stunting}

Pada penelitian ini tidak ditemukan adanya hubungan antara konsumsi Zink dengan kejadian stunting $(p>0,05)$. Hasil yang berbeda ternyata ditunjukkan dari Anindita (2012) yang menyatakan bahwa ada hubungan antara tingkat kecukupan zink dengan kejadian stunting. Ketidak-bermaknaan hubungan yang ditemukan dalam penelitian ini bisa disebabkan karena sebagian besar kelompok anak yang stunting (kasus) maupun kelompok kontrol memiliki tingkat konsumsi zink yang rendah dan besarnya relatif sama. Rendahnya tingkat konsumsi zink pada anak balita sangat mungkin disebabkan 
akses bahan makanan sumber zink di wilayah penelitian cenderung kurang beraneka ragam.

\section{Hubungan ASI Eksklusif dengan Stunting}

Pada penelitian yang dilaksanakan di Kelurahan Sukaraja ini diketahui bahwa anak yang diberikan ASI secara eksklusif jumlahnya sangat rengah dan secara statistik ada hubungan yang bermakna antara pemberian ASI eksklusif dengan kejadian stunting. Besarnya resiko anak di Kelurahan Sukaraja untuk menderita stunting karena tidak diberikan ASI secara eksklusif adalah 4.03 kali.

Anak yang tidak diberikan ASI secara eksklusif menandakan bahwa anak tersebut sudah diberikan makanan lain selain ASI sebelum usianya mencapai 6 bulan. Hasil penelitian Hien dan Kam (2008) menyatakan bahwa resiko anak menjadi stunting 3,7 kali lebih tinggi pada balita yang tidak diberi ASI secara Eksklusif.

Hasil penelitian Fikadu, dkk. (2014) di Ethiopia Selatan menunjukkan bahwa balita yang tidak diberikan ASI eksklusif selama 6 bulan pertama memiliki risiko yang lebih besar terhadap kejadian stunting. Penelitian yang dilakukan oleh oleh Purnamasari, dkk (2009) pada 72 balita menunjukkan bahwa pemberian ASI yang tidak Eksklusif merupakan faktor resiko terjadinya growth faltering (gagal tumbuh) pada bayi umur 2-6 bulan. Kemudian hasil penelitian Bentian dkk (2015) juga menunjukkan bahwa proporsi balita stunting lebih banyak disebabkan oleh pemberian MP ASI pada usia $<6$ bulan di bandingkan pada balita yang tidak diberi MP ASI pada usia <6 bulan. Pemberian MP-ASI yang terlalu dini dapat meningkatkan risiko penyakit infeksi seperti diare karena MP- ASI yang diberikan tidak sebersih dan mudah dicerna seperti ASI. Selain pemberian MP-ASI yang terlalu dini, terlambatnya memberikan MP-ASI juga menyebabkan pertumbuhan dan perkembangan balita menjadi terhambat karena kebutuhan gizi balita tidak tercukupi.

Berdasarkan hasil wawancara dengan ibu responden dapat diketahui bahwa anak mendapatkan ASI secara eksklusif hanya sampai usia 3 bulan dengan alasan karena ASI tidak keluar $(59,2 \%)$, jumlah ASI sedikit $(14,8 \%)$, ibu sakit $(5,9 \%)$, dan lain-lain $(37,1 \%)$. Munculnya alasan-alasan tersebut sangat mungkin dipengaruhi oleh ketidak tahuan ibu tentang manfaat ASI bagi bayi. Oleh sebab itu peran petugas kesehatan sangat penting pada saat ibu sedang hamil untuk memberikan pemahaman kepada ibu tentang manfaat ASI bagi anak dan juga memberikan keterampilan ibu tentang perawatan payudara saat hamil. Hal ini dapat dilakukan melalui kunjungan rumah atau pada saat ibu memeriksakan kehamilannya.

\section{Hubungan Inisiasi Menyusui Dini (IMD) dengan Stunting}

Hasil penelitian ini menunjukkan bahwa secara statistik tidak ada hubungan yang bermakna antara IMD dengan kejadian stunting $(p>0,05)$. Hasil penelitian di Kelurahan Sukaraja ini sejalan dengan hasil penelitian Lubis dkk (2018) yang menyebutkan bahwa IMD tidak berhubungan signifikan dengan kejadian stunting $(p=0,593)$. Kemudian hasil penelitian Paramashanti, dkk (2015) juga menyatakan bahwa tidak ada hubungan yang signifikan antara IMD dengan stunting.

Hasil penelitian ini tidak sesuai dengan WHO (2013) yang menyebutkan bahwa salah satu faktor yang dapat menyebabkan stunting adalah karena inisiasi menyusui yang terlambat.

Tidak ditemukannya hubungan antara IMD dengan kejadian stunting pada anak di Kelurahan Sukaraja bisa terjadi karena bias informasi. Ibu menganggap sudah diberikan perlakuan IMD oleh bidan atau dokter yang menolong persalinannya padahal bayi belum sempat mendapatkan kesempatan menyusui. Oleh sebab itu, penolong persalinan (baik bidan maupun dokter) harus bisa memastikan IMD berjalan dengan semestinya.

\section{Hubungan Riwayat Penyakit Infeksi dengan Stunting}

Hasil analisa bivariat yang dilakukan pada penelitian di Kelurahan Sukaraja menunjukkan bahwa ada hubungan yang bermakna antara riwayat penyakit infeksi responden dengan kejadian stunting. Hasil penelitian Priyono dkk (2015) juga menunjukkan bahwa ada hubungan yang bermakna antara penyakit infeksi dengan kejadian stunting pada anak balita usia 12-36 bulan di wilayah kerja Puskesmas Randuagung Kabupaten Lumajang. Demikian pula hasil penelitian Masithah, dkk (2005) yang menyatakan bahwa status kesehatan berupa penyakit infeksi memiliki hubungan positif terhadap indeks status gizi TB/U.

Penyakit infeksi yang sering diderita anak balita adalah diare dan infeksi saluran pernapadan akut (ISPA). Jika kondisi ini terjadi secara berulang-ulang dalam jangka waktu yang lama, maka dapat menyebabkan terjadinya masalah gizi. Hal ini didukung dengan teori yang dikemukakan oleh Hidayat dkk (2011) yang menyatakan bahwa terjadinya masalah gizi 
pendek (TB/U) sebagai akibat dari keadaan yang berlangsung lama seperti kemiskinan, dan pola asuh yang kurang tepat. Rendahnya sanitasi dan kebersihan lingkungan dapat memicu gangguan saluran pencernaan, yang membuat energi untuk pertumbuhan teralihkan kepada perlawanan tubuh menghadapi infeksi (Schmid, 2014) Hasil penelitian lain menyebutkan bahwa semakin sering seorang anak menderita diare, maka semakin besar pula ancaman stunting untuknya (Cairncross, 2013). Selain itu, saat anak sakit, lazimnya selera makan mereka pun berkurang, sehingga asupan gizi makin rendah.

Untuk mencegah kejadian stunting karena faktor penyakit infeksi, setiap keluarga perlu menjaga sanitasi lingkungan rumah. Oleh sebab itu peran petugas kesehatan, termasuk kader dan tokoh masyarakat, sangat penting untuk meningkatkan gerakan hidup bersih dalam masyarakat karena potensi stunting bisaberkurang jika ada intervensi yang terfokus pada perubahan perilaku dalam sanitasi dan kebersihan. Intervensi sanitasi dan kebersihan dengan jangkauan 99\% dilaporkan berdampak pada berkurangnya diare sebesar $30 \%$, yang kemudian menurunkan prevalensi stunting sebesar $2,4 \%$.

\section{Hubungan Status Gizi Ibu $(\mathrm{TB} / \mathrm{U})$ dengan Stunting}

Hasil penelitian ini menunjukkan bahwa tidak ada hubungan yang bermakna antara status gizi ibu dengan kejadian stunting pada anak $(p>0,05)$. Berbeda dengan hasil penelitian Oktarina (2014) yang menyatakan bahwa ada hubungan antara tinggi badan ibu dengan kejadian stunting pada balita. Hal yang sama juga ditunjukkan oleh hasil penelitian di Cina yang menunjukkan adanya hubungan antara tinggi badan ibu dengan kejadian stunting. Tinggi badan ibu kurang dari $155 \mathrm{~cm}$ lebih beresiko memiliki anak stunting (Yang, dkk, 2010). Postur tubuh ibu juga mencerminkan tinggi badan ini dan lingkungan awal yang akan memberikan kontribusi terhadap tinggi badan anak sebagai faktor independen (Taguri, dkk, 2008).

Hasil penelitian yang dilakukan Rahayu (2011) juga menyatakan bahwa anak yang lahir dari ibu atau ayah yang pendek berisiko menjadi stunting. Hal serupa juga dinyatakan dari hasil penelitian Yang (2010) yang menyatakan bahwa tinggi badan ibu yang pendek berisiko 1,3 kali memiliki balita stunting dibandingkan dengan dengan ibu yang memiliki tinggi badan yang tinggi.
Terjadinya perbedaan hasil penelitian ini dengan hasil-hasil penelitian yang telah disebutkan di atas bisa terjadi karena alat ukur tinggi badan yang digunakan mungkin berbeda. Dalam penelitian di Kelurahan Sukaraja, tinggi badan ibu diukur dengan menggunakan mikrotoise sedangkan penelitian lain mungkin menggunakan pengukuran detekto. Hal lain yang bisa menjadi faktor pembeda adalah pengkategorian hasil ukur. Dalam penelitian ini, status gizi ibu yang diukur dengan menggunakan indeks TB/U hanya dibagi menjadi 2 kategori yaitu pendek dan normal (tinggi dimasukkan dalam kategori normal). Selain itu jumlah sampel yang digunakan untuk masing-masing penelitian juga berbeda.

\section{Hubungan Usia Ibu Melahirkan dengan Stunting}

Hasil analisa bivariat dari penelitian ini menunjukkan bahwa tidak ada hubungan yang bermakna antara usia ibu melahirkan dengan kejadian stunting $(p>0,05)$. Hal ini sesuai dengan teori yang dikemukakan Cunningham (2006) bahwa usia reproduksi perempuan adalah 20-35 tahun. Pada usia kurang dari 20 tahun maka organ-organ reproduksi belum berfungsi sempurna sedangkan pada usia di atas 35 tahun telah terjadi penurunan reproduktif. Penelitian yang dilakukan oleh Jiang, (2015) menyebutkan bahwa kehamilan diatas usia 35 tahun memiliki resiko melahirkan anak stunting 2,74 kali. Tidak ditemukannya hubungan antara umur ibu melahirkan dengan kejadian stunting dalam penelitian ini bisa disebabkan karena ibu yang berada pada kategori melahirkan pada usia beresiko jumlahnya sangat kecil. Selain itu mungkin saja penetapan batas usia juga berbeda dengan yang digunakan penelitian lainnya.

\section{Hubungan Riwayat Kelahiran dengan Stunting}

Hasil penelitian di Kelurahan Sukaraja menunjukkan bahwa secara statistik ada hubungan yang bermakna antara riwayat kelahiran (prematur) dengan kejadian stunting. Sejalan dengan itu, sebuah penelitian di Tangerang menunjukkan bahwa bayi yang lahir prematur berisiko 2 kali pada usia 6-12 bulan untuk mengalami stunting.

Usia kehamilan merupakan faktor risiko kejadian stunting balita usia 12 bulan. Pertumbuhan pada bayi prematur mengalami keterlambatan dikarenakan usia kehamilan yang singkat dan adanya retardasi pertumbuhan linear 
di dalam kandungan. Bayi yang lahir cukup bulan apabila asupan gizinya kurang juga akan mengalami growth faltering. Hal ini akan bertambah berat jika ditambah dengan paparan penyakit infeksi. Sebaliknya, bayi prematur yang mengalami growth faltering jika diberikan dukungan asupan gizi yang adekuat maka pola pertumbuhan normal dapat terkejar (catch up).

\section{Hubungan Jarak Umur dengan Stunting}

Hasil penelitian di Kelurahan Sukaraja menyatakan bahwa tidak ada hubungan yang bermakna antara jarak umur kelahiran dengan kejadian stunting $(p>0,05)$. Hasil yang sama ditunjukkan dari hasil penelitian Fajrina (2016) bahwa tidak ada hubungan yang signifikan antara jarak kelahiran dengan kejadian stunting pada anak.Hasil penelitian ini juga sejalan dengan penelitian yang dilakukan oleh Nadiyah (2014) yang menyebutkan bahwa jarak kelahiran tidak signifikan berhubungan dengan stunting dengan nila $p$-value $0,176(p<0,05)$

Tidak ditemukannya hubungan antara jarak umur kelahiran dengan kejadian stunting bisa terjadi karena jumlah sampel yang masih sedikit sementara jumlah variabel yang diteliti banyak. Selain itu batasan jarak umur yang digunakan juga tidak sama.

\section{Hubungan Tingkat Pendidikan Ibu dengan Stunting}

Dalam penelitian ini ditemukan adanya hubungan yang bermakna antara tingkat pendidikan ibu dengan kejadian stunting. Hasil penelitian Ni'mah (2016) juga menunjukkan hal yang sama bahwa pendidikan ibu merupakan faktor yang berhubungan dengan kejadian

\section{DAFTAR PUSTAKA}

Adair, L. S., Fall, C. H., Osmond, C., Stein, A. D., Martorell, R., Ramirez-Zea, M., ... \& Micklesfield, L. (2013). Associations of linear growth and relative weight gain during early life with adult health and human capital in countries of low and middle income: findings from five birth cohort studies. The Lancet, 382(9891), 525-534.

Anindita, P. (2012). Hubungan Tingkat Pendidikan Ibu, Pendapatan Keluarga, Kecukupan Protein \& Zinc dengan Stunting (Pendek) pada Balita Usia 635 Bulan di Kecamatan Tembalang Kota stunting pada balita. Hasil penelitian lain (Ramli dkk, 2009) juga membuktikan bahwa tingkat pendidikan ibu berhubungan secara signifikan dengan kejadian stunting pada balita. Hal ini bisa disebabkan karena peran pengasuhan lebih besar dilakukan oleh ibu. Penelitian di Kamboja oleh Ikeda dkk. (2013), dan Tiwari dkk. (2014) di Nepal juga menunjukkan bahwa pendidikan ibu merupakan faktor risiko kejadian stunting pada anak di bawah lima tahun.

Ibu dengan pendidikan tinggi mempunyai pengetahuan yang lebih luas tentang praktik perawatan anak serta mampu menjaga dan merawat lingkungannya agar tetap bersih (Taguri $\mathrm{dkk}$, 2009). Orang tua terutama ibu yang mendapatkan pendidikan lebih tinggi dapat melakukan perawatan anak dengan lebih baik daripada orang tua dengan pendidikan rendah.Tingkat pendidikan ibu turut menentukan mudah tidaknya seorang ibu dalam menyerap dan memahami pengetahuan gizi yang didapatkan. Pendidikan diperlukan agar seseorang terutama ibu lebih tanggap terhadap adanya masalah gizi di dalam keluarga dan diharapkan bisa mengambil tindakan yang tepat sesegera mungkin (Suhardjo, 2003).

\section{SIMPULAN}

Bahwa faktor konsumsi protein, konsumsi zink, IMD, status gizi ibu, umur ibu melahirkan, dan jarak kelahiran tidak berhubungan secara bermakna dengan kejadian stunting anak usia 724 bulan di Kelurahan Sukaraja, sedangkan faktor konsumsi energi, ASI eksklusif, Riwayat penyakit infeksi, riwayat kelahiran prematur, dan pendidikan ibu berhubungan secara bermakna dengan kejadian stunting.
Semarang. Jurnal Kesehatan Masyarakat Universitas Diponegoro, 1(2).

Anugraheni, H. S., \& Kartasurya, M. I. (2012). Faktor risiko kejadian stunting pada anak usia 12-36 bulan di Kecamatan Pati, Kabupaten Pati. (Tesis, Diponegoro University).

Aridiyah, F. O., Rohmawati, N., \& Ririanty, M. (2015). Faktor-faktor yang Mempengaruhi Kejadian Stunting pada Anak Balita di Wilayah Pedesaan dan Perkotaan (The Factors Affecting Stunting on Toddlers in Rural and Urban Areas). Pustaka Kesehatan, 3(1), 163-170. 
Bentian, I., Mayulu, N., \& Rattu, A. J. M. (2015). Faktor Resiko Terjadinya Stunting Pada Anak TK Di Wilayah Kerja Puskesmas Siloam Tamako Kabupaten Kepulauan Sangihe Propinsi Sulawesi Utara. JIKMU, 5(1).

Cairncross, Sandy. (2013). "Linking toilets to stunting". UNICEF ROSA 'Stop Stunting' Conference, New Delhi.

Cunningham G, Leveno KJ, Bloom SL, Hauth JC, Gilstrap LC, Wenstrom KD. (2006). Williams Obstetrics. New York: McGraw Hill Medical

Dinas Kesehatan Kota Bandar Lampung. (2017). Profil Kesehatan Kota Bandar Lampung. Bandar Lampung.

Espo, M., Kulmala, T., Maleta, K., Cullinan, T., Salin, M. L., \& Ashorn, P. (2002). Determinants of linear growth and predictors of severe stunting during infancy in rural Malawi. Acta paediatrica, 91(12), 1364-1370.

Fajrina, N. (2016). Hubungan Faktor Ibu Dengan Kejadian Stunting Pada Balita di Puskesmas Piyungan Kabupaten Bantuk. (Skripsi, Universitas Aisyiyah Yogyakarta).

Fikadu, T., Assegid, S. \& Dube, L. (2014). Factor associated with stunting among children age 24 to 59 months in Meskan District, Gurage Zone, South Ethiopia: A case-control study. BMC Public Health, 14(800). Tersedia: http://www.biomedcentral.com/14712458/14/800.

Fitri. (2012). Berat Lahir Sebagai Faktor Dominan terjadinya stunting pafda balita 12 - 59 bulan di Sumatera (Analisis Data Riskesdas 2010). (Tesis, FKM-UI).

Hidayat TS dan Fuada N. (2011). Hubungan Sanitasi Lingkungan, Morbiditas, dan Status Gizi Balita di Indonesia. Penelitian Gizi Makan. 34 (2): 104-113.

Hien, NN. dan Kam, S. (2008). Nutritional Status and the Characteristics Related to Malnutrition in Children Under Five Years og Age in Nghean, Vietna. J Prev Med Public Health. 41 (4): 232-240.

Ikeda, N., Yuki, I., \& Shibuya, K. (2013). Determinants of reduced child stunting in Cambodia: Analysis of pooled data from three demographic and health surveys. Bulletin of the World Health Organization, 91, 341-349.

Jiang, Y., Su, X., Wang, C., Zhang, L., Zhang, X., Wang, L., \& Cui, Y. (2015). Prevalence and risk factors for stunting and severe stunting among children under three years old in mid-western rural areas of $\mathrm{C}$ hina. Child: care, health and development, 41(1), 45-51.

Judge TA, Cable DM. (2004). The effect of physical height on workplace success and income: preliminary test of a theoretical model. J Appl Psychol, 89(3):428-441.

Kemenkes RI. 2016. Buku Saku Pemantauan Status Gizi dan Indikator Kinerja Gizi Tahun 2015. Jakarta: Dirjen Kesehatan Masyarakat Direktorat Gizi Masyarakat.

Kemenkes RI. (2018). Buku Saku Pemantauan Status Gizi dan Indikator Kinerja Gizi Tahun 2017. Jakarta: Dirjen Kesehatan Masyarakat Direktorat Gizi Masyarakat

Lee J, Houser RF, Must A, de Fulladolsa PP, \& Bermudez OI. (2010). Disentangling nutritional factors and household characteristics related to child stunting and maternal overweight in Guatemala. Economics and Human Biology, 8(2), 188196.

Lubis, F. S. M., Cilmiaty, R., \& Magna, A. (2018). Hubungan Beberapa Faktor Dengan Stunting Pada Balita Berat Badan Lahir Rendah. Jurnal Kesehatan Kusuma Husada, 9(1).

Martorell R, Horta BL, \& Adair LS et al. (2010) Consortium on Health Oriented Research in Transitional Societies Group. Weight Gain in the First Two Years of Life Is an Important Predictor of Schooling Outcomes in Pooled Analyses from Five Birth Cohorth from Low and Midle Income Countries. J. Nutr, 140, 348-354.

Masithah T, Soekirman, dan Martianto D. (2005). Hubungan Pola Asuh Makan dan Kesehatan dengan Status Gizi Anak Batita di Desa Mulya Harja. Jurnal Media Gizi Keluarga. 29 (2): 29-39

Meilyasari, Friska., Muflihah Isnawati. (2014). Faktor Risiko Kejadian Stunting Pada Balita Usia 12 Bulan di Desa Purwokerto Kecamatan Patebon Kabupaten Kendal. Journal of Nutrition College, Volume 3, Nomor 2, Tahun 2014, Halaman 16-25.

Nadiyah, N., Briawan, D., \& Martianto, D. (2014). Faktor Risiko Stunting Pada Anak Usia 0-23 Bulan Di Provinsi Bali, Jawa Barat, Dan Nusa Tenggara Timur. Jurnal Gizi dan Pangan, 9(2).

Ni'mah K \& Siti Rahayu Nadhiroh. (2016). Faktor yang berhubungan dengan kejadian stunting pada balita. Media Gizi Indonesia, Vol. 10, No. 1 Januari-Juni 2015: hlm. 13-19.

Oktarina, Z., \& Sudiarti, T. (2014). Faktor Risiko Stunting Pada Balita (2-59 Bulan) Di 
Sumatera. Jurnal Gizi dan Pangan, 8(3), 177-180.

Paramashanti, B.A., Hadi, H.,Gunawan, I.M.A. (2015). Hubungan antara praktik pemberian ASI eksklusif dan stunting pada anak usia 6-23 bulan di Indonesia. Jurnal Gizi dan Dietetik Indonesia. Vol.3. No.3. 170-182.

Priyono, D. I. P., Sulistiyani, S., \& Ratnawati, L. Y. (2015). Determinan Kejadian Stunting pada Anak Balita Usia 12-36 Bulan di Wilayah Kerja Puskesmas Randuagung Kabupaten Lumajang (Determinants of Stunting among Children Aged 12-36 Months in Community Health Center of Randuagung, Lumajang Distric). Pustaka Kesehatan, 3(2), 349-355.

Purnamasari, D. U., M. I. Kartasurya dan A. Kartini. (2009). Determinan growth faltering (guncangan pertumbuhan) pada bayi umur 2-6 bulan yang Lahir dengan dengan Berat Badan Normal. Media Medika Indonesia, Volume 43 Nomor 5 hal 242.

Rahayu, L. S., \& Sofyaningsih, M. (2011). Pengaruh BBLR dan pemberian ASI eksklusif terhadap perubahan status stunting pada balita di kota dan kabupaten Tangerang provinsi Banten. In Prosiding Seminar Nasional "Peran Kesehatan Masyarakat dalam Pencapaian MDGs di Indonesia". Universitas Muhammadiyah Prof Dr. Hamka.

Ramli, Agho, K. E., Inder, K. J., Bowe, S. J. Jacobs, J. \& Dibley, M. J. (2009). Prevalence and risk factors for stunting and severe stunting among under-fi ves in North Maluku Province of Indonesia.BMC
Pediatrics, 9-64. doi:10.1186/1471-24319-64.

Schmidt, Charles W. (2014). "Beyond malnutrition: the role of sanitation in stunted growth." Environmental health perspectives, 122.11: A298.

Suhardjo. (2003). Berbagai cara pendidikan gizi. Jakarta: Bumi Aksara.

Taguri, A., Betilmal, I., Mahmud, S. M.,Ahmed, A. M., Goulet, O., Galan, P., \& Hercberg, S. (2009). Risk factor for stunting among under five in Libya. Public Health Nutrition, 12(8), 1141-1149.

Tiwari, R., Ausman, L. M., Argho, K. E. (2014). Determinants of stunting and severe stunting among under-fives: evidence from 2011 Nepal Demographic and Health Survey. BMC Pediatrics, 14, 239. www.biomedcentral.com/14712431/14/239

United Nations Children's Fund (UNICEF). (2005). The State of The World Children. New York: Oxford University Press

WHO. (2013). WHA global nutrition targets 2025: Stunting policy brief. Geneva: World Health Organization.

Xiaoli W, Beng H, \& Sufang G et al. (2009). Stunting and overweight in the WHO child growth standard: malnutrition among children in poor area in China. Public Health Nutrition, 12(11), 1991-1998.

Yang, X. L., Ye, R. W., Zheng, J. C., Jin, L., Liu, J. M., \& Ren, A. G. (2010). Analysis on influencing factors for stunting and underweight among children aged 3-6 years in 15 counties of Jiangsu and Zhejiang provinces. Zhonghua liu xing bing xue za zhi= Zhonghua liuxingbingxue zazhi, 31(5), 506-509. 